\title{
PATRONS OF OTTOMAN MOSQUES IN GREECE RECONSIDERED IN LIGHT OF THE IERAPETRA MOSQUE OF CRETE
}

Received August $7^{\text {th }}, 2018$ | Accepted September $6^{\text {th }} 2018$ | Available online June $15^{\text {th }} 2019$ |

| DOI : http://dx. doi.org/10.18860/iia.v5i3.5365 |

\section{Ahmed Ameen}

Fayoum University

Department of Islamic Archaeology

Fayoum, Egypt

Ahmed.ameen@fayoum.edu.eg

\begin{abstract}
The subject of this paper is based on a reconsideration of patrons of Ottoman mosques in Greece in light of the analyzed study of the lerapetra Mosque of the island of Crete. This paper draws a layout of the lerapetra city under the Ottomans based on the relevant sources with particular reference to the salnames and old photographs. It examines in details about the architecture, the inscriptions, and the historical context of lerapetra mosque. This paper also corrects the reading of some inscriptions and proposes reading for some Arabic inscriptions for the first time. Based on a survey by the author conducted between 2006 and 2016, there are around eighty Ottoman historical mosques in Greece that still exist. It concludes that the lerapetra mosque is a notable example with its architecture, inscriptions, and fountain. Moreover, it is one of the rare cases in Greece that were built by the contribution of the Muslim community of the city.
\end{abstract}

KEYWORDS:

Islamic Architecture; Ottoman Mosque; Arabic Inscription; Crete; Greece.

\section{INTRODUCTION}

Mosque construction was largely sponsored by the state through its ruling class and high ranking officials; this was a typical scheme in so-called Islamic cities governed by Muslims. Whereas, in non-Islamic countries, where Muslim minorities lived such as China [1] and in numerous Islamic regions such as Oman [2]. It was the duty of wealthy public figures or traders of the Muslim community, belonging to the latter just as most rural mosques even within the Islamic-governed regions.

There are around eighty Ottoman historical mosques in Greece still in existence. These mosques have considerable historical and architectural value; date from a period ranging from roughly the second half of the 14th century until the first decades of the 2oth century [3].

The founders of these mosques, excluding a few examples, belong to the higher classes in the Ottoman administration, including Sultans and their inner circles, commanders, and high ranking officials. Furthermore, there are some mosques founded, according to their foundation inscriptions, by Greek Muslims except two which were built by Muslim inhabitants. Figure 1 shows the results of a survey showing the founders' identity of 75 historical mosques in Greece. Mosques of influential statesmen, including grand commanders (with positions/titles: Grand Vizier, Vizier, Veli, Pasha, Bey, and Reis) represent the most substantial proportion of patrons who commissioned the building of these mosques. This category, in addition to the relatively high ranking officials (with positions/titles like Kadi, Effendi, Agha, and Baba) is responsible for building more than two-thirds of the mosques.

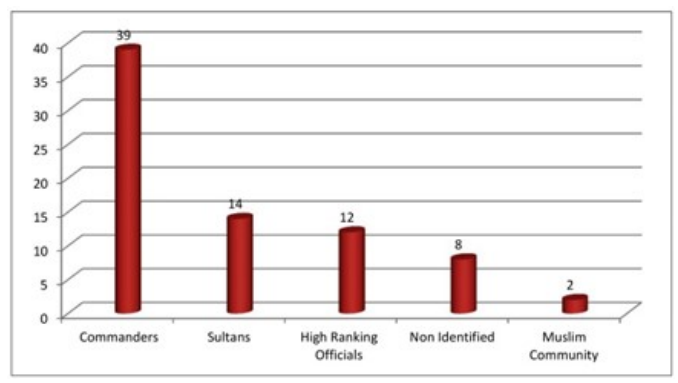

Fig. 1. Numbers of the Ottoman Mosques in Greece according to their founders' identity

This percentage increases if we take into consideration the fourth category, non-identified mosques, which likely also belong to those two categories. The second category, the number of Ottoman Sultans and their families' mosques, is remarkable. While contrasting these figures, it is also important to take into consideration the architecture, design, architect, and location as well. Among the buildings of both first categories, there are three mosques commissioned by women (Hafsa daughter of the commander Hamza Bey, a grandson of Ghazi Evrenos Bey, [4] in Thessaloniki 1467/1468, Princess Selçuk Sultân (d. 1509), daughter of Sultan Bayezid II in Serres [5], [6], [7], [8], and Valide Mosque (before 1791) in Mytilini, dedicated to Huri Hanim the mother of Um Gulsum, daughter of the vice governor Khalil Agha) [9], [10]. 
The last category comprises the two mosques built by Muslim communities, the lerapetra Mosque of Crete and the Yeni Camii (New Mosque) of Thessaloniki (1902). The latter (Fig. 2) was built, according to its foundation inscription, by the Dönmeh community of Thessaloniki -Muslims of Sephardic Jewish origin that had converted to Islam by the $17^{\text {th }}-18^{\text {th }}$ centuries- [11], [12] under the patronage of Haci Mehmet Hayri Pasha, a field marshal in the Third Army. It was designed by the Italian architect Vitaliano Poselli.
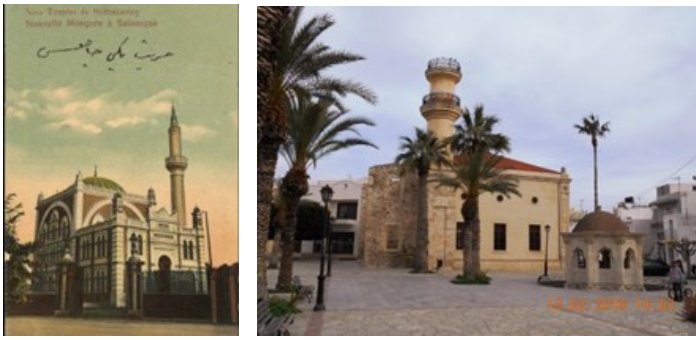

Fig. 2: Yeni Camii. Early 20th-century postcard. [3]

Fig. 3: The lerapetra Mosque with its ablution fountain.

The other example in this last category, the lerapetra Mosque (Fig. 3) of Crete, our main topic here, is distinct because not only it was built by contributions of the city's Muslim community, but there is also evidence of participation from the Greek Muslims in founding the mosques. In the next sections, we will investigate the lerapetra Mosque.

\section{lerapetra Under The Ottomans}

lerapetra is the southern city of the prefecture of Lasithi, Crete, the Greek Mediterranean Island. lerapetra was dominated by the Ottomans from 1647 to 1905 [13]. The Salnâme of the Crete province (Girid Vilayet) from 1310 (1893) describes lerapetra as a Kaza among four kazas, together with Mrambila, Viano and Estia, that have been formed the LAȘiD (لاشيد,Yenișehir, Lassithi, Lasithi, $\wedge a \sigma^{\prime}(\theta$ ) sandjak; one of the five sandjaks formed the Girit Eyâleti, it was composed of four districts (nahia) and 19 villages, with a center the citadel of lerapetra "merkz kaza" [14]. The same source states that in Laşid Sandjak were 35 camii, 12 mescids, one medrese, and ten çeşme [14]. lerapetra kaza had seven Christian mektep for male children, with 322 pupils and eight male teachers. On the other hand, there were two Muslim male school-rushdia (high school), six Muslim mektep for male children, and two Muslim mektep for females; with total 502 male and 289 female pupils, and ten male and two female teachers [14]. Another Salnâme (1293H/1876) mentions the governmental ottoman buildings that were found in the lerapetra kaza, including one castle, one gunpowder store, one armor store, four police station houses, one government headquarter, one police station office, one prison, one customs administration, and seven towers [15]. Also, there were 29 flour mills, 158 oil-presses, 49 shops. In 1293H/1876, the Muslims numbered 1654 (435 houses), the Christians were 3676 (760 homes), and no Jewish [15]. The names of officials of the Ottoman administrative structure of lerapetra correspond with the same inhabitants' proportion, as declares the Salnâmes that around two-thirds were Greek [16]. This composition is only in Crete thanks to the Pact of Halepa Oct. 1878 [17].
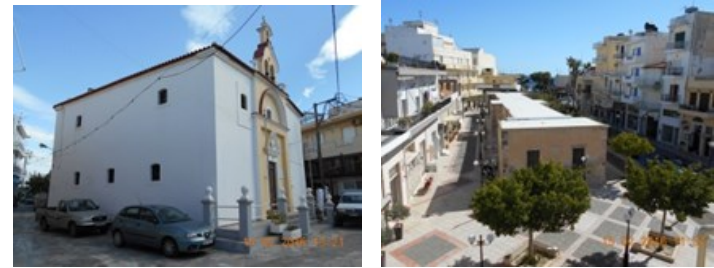

Fig. 4: Ankebut Ahmed Paşa Mosque (Agios loannes Church) Fig. 5: The 19th-century Medrese of lerapetra

In lerapetra under the Ottomans, as mentioned above, many buildings were built; among which two mosques still survive (Ankebut Ahmed Paşa Mosque Fig. 4, 17th century, functions now Agios loannes Church, [18] and the Mosque under discussion "lerapetra Mosque"), one medrese (end of the 19th century, Fig. 5) and some fountains (çeşme) [19].

\section{The lerapetra Mosque (Figs. 3, 6-13)}

The lerapetra Mosque is located in Lochagou Ioanni Mamounaki Square in Kato Mera, the center of the old city of lerapetra. It has an octagonal ablution fountain dated to 7 Rajab 1289 AH (10 Sep. 1872); two decades earlier than the completion of the proper mosque in 1309 A.H (1891-1892), as verified by the inscriptions of both.

The lerapetra Mosque is a 19th-century mosque consisting of an almost perfectly square prayer hall, with internal dimensions of 11.65 by 11.75 meters, covered with a hipped wooden roof, which is covered on the exterior with ceramic tiles, supported directly on the walls ( 0.78 meters of thickness). There was a threebay portico fronting the prayer hall; its traces can still be seen. According to a 1900 s photo [20], the portico was a double-storey building covered with an inclined roof (Fig. 6). Short lateral walls of the porticos differ in both building technique and alignment from those of the prayer hall; suggesting that the portico was a later addition (Figs. 10, 11). The portico was divided into two compartments, which envelope the entrance corridor at the ground level. Its upper storey, as suggested by the solid foundations of the portico's walls, was under intensive use. The ground compartments were accessed through the entrance corridor on both sides, while it is likely a wooden stair in one of its internal side corners provided access to the upper storey. This storey was connected with the prayer hall through three big arched openings (which were walled up) opening up to three new smaller round windows. This portico design is found in the late 19th century and is a distinct Ottoman mosque in the Greek Islands. It is an s example of the Grand Vizier Fazl Ahmed Paşa Köprülü Mosque in Irakleio. The function of this unit is not clear, but its site suggests the probability of it being used as a women's gallery. 


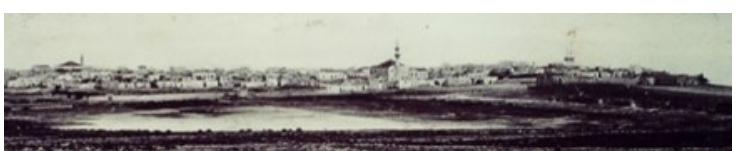

Fig. 6: General view of the lerapetra city, with a focal point the lerapetra Mosque. 1900s postcard [20]

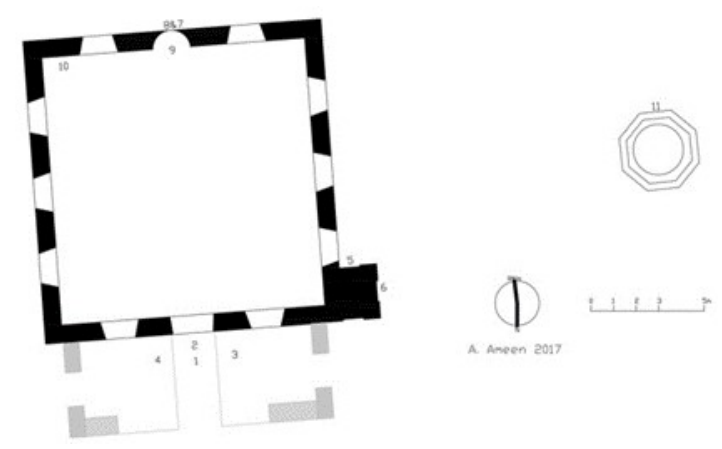

Fig. 7. lerapetra Mosque and its ablution fountain, Numbers on plan refer to the inscriptions

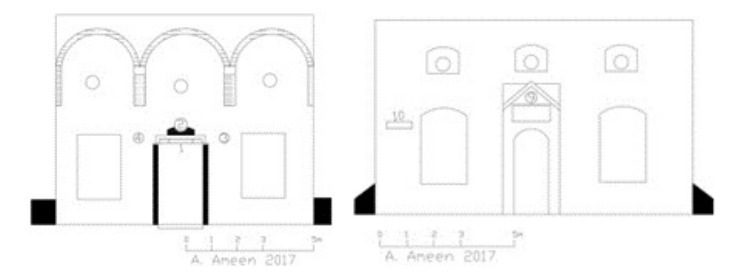

Fig. 8. Section of the main façade Fig. 9. Section of the qibla wall façade

There is a single minaret in the prayer-halls northwest corner (Figs. 3. 10). A 1953 earthquake caused the loss of its upper section. Its base is rectangular built of porous stone, on which rests the cylindrical shaft with its two balconies. Access to the minaret was from the corresponding location in the interior of the prayer hall leading right to its upper storey; traces of its door opening (now walled up) are still visible (Fig. 12). There likely was an internal gallery or a wooden staircase leading to this door. According to the above 1900 s photo (Fig. 6), the minaret was a typical Ottoman design with a cylindrical shaft with two balconies (şerefe), the upper smaller than the lower. Its shaft reduces in diameter as it rises upward, topped with a sharp (pencil point) hood. The current unusual thickness of the minaret's shaft is a result of a coating layer which encircled it.
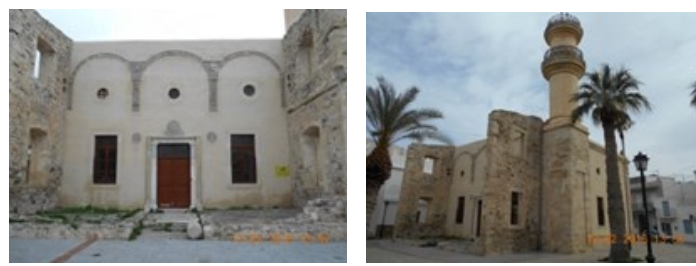

Fig. 10: lerapetra Mosque, the minaret, and the portico's traces Fig. 11: the portico and the prayer hall's main façade

About 11 meters west of the mosque there is an ablution fountain, the most beautifully preserved in Greece. Its octagonal dome, the basins, and the water outlets are still seen on all eight sides. The walls are topped with a cordon which continues on all sides. It ends on the southern side with two confronted finecarved snakeheads opening their jaws holding the foundation's inscription. This ornament, the caduceus, has symbolic and mythological meanings rooted in both ancient Greece [21] and old Turkish lore [22]. Among many symbolic meanings of the snake figures, healing is the most suggested due to its relation to the religious function of the structure.

It is worth mentioning that the architecture of the lerapetra Mosque, along with its architectural elements such as the mihrab, the minaret, the fountain architecture including its roofing, dimensions and the positions of the outlets, suggest an association with the Sunni Hanafi School of thought [23].
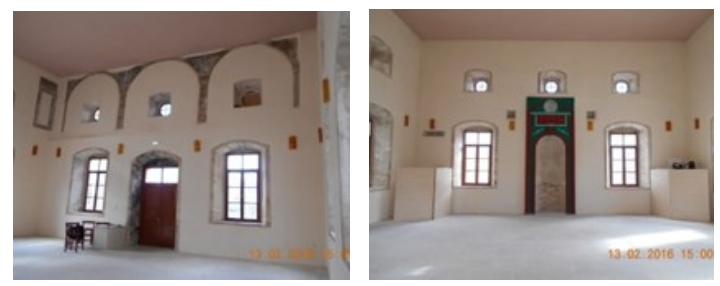

Fig. 12: lerapetra Mosque, the interior

Fig. 13: lerapetra Mosque, the interior qibla wall

\section{An INSCRIPTIVE MAP OF THE IERAPETRA MOSQUE}

The inscriptive map of the lerapetra Mosque is unusual (Figs. 7-9), and indicates that the Mosque had been renovated. Only the site, the dimensions, some inscriptions, some architectural elements, and building material from the original remain. The various types of heterogeneous characteristics shown in the inscriptions imply multiple patrons and phases throughout its history.

The total number of the inscriptions of the Mosque Complex is eleven which can be found on one separated ablution fountain and ten from the proper Mosque, two inside the Mosque on the qibla wall, and eight on the exterior. The latter are located as follows: four on the main façade around the portal of the Mosque, two on the qibla wall, and two on the minaret's base. From all of the inscriptions on the fountain and the minaret, seven are in Arabic (the last one above the door (Inscription no. 2, Fig. 15)) is likely in Arabic, but it is not for certain because it is poorly preserved) and three in Ottoman Turkish. Seven inscriptions are religious, including passages of the Quran, Hadith or supplications. Some inscriptions are outlined on a board or panel in which the text is inscribed, while others have text with a distinct arrangement. Five of the inscriptions are rectangular, and six are round; among the latter, one has a distinct frame and form. Six of the inscriptions, according to their text arrangement, are inscribed in uniformed lines, three of which are set in cartouches, while the others are not. The other three inscriptions are in the Ottoman Tughra calligraphy style, and the last two are an intertwined 6-points star. All inscriptions are executed in large thuluth (jali; Turkish celi), except the one above the door of the mosque (Inscription no. 2, 
Fig. 15) which is executed in ta?lyiqq. The inscriptions are carved in both marble and stone.

The inscriptions of the lerapetra Mosque provide an interesting example of the visual impact of an artistic media having practical day-to-day use. It explained the positioning of the inscriptions, excluding those of the entrance and on the interior of the mosque visible to the congregants and placed towards the south in the direction of a residential neighbourhood and the fort. It also may explain why the qibla wall on the exterior has two inscriptions. Lastly, the inscription on the fountain has the most visual impact (Inscription no. 11, Fig. 27).

\section{Inscription No. 1 (Fig. 14)}

This inscription is carved in white marble linte crowning the opening of the single door of the mosque. The dimensions of the text area are 17 by 165 centimeters and together with the decorated lintel are 30 by 190 centimeters, at the height of 3.20 meters from the floor. The scribe retained the symmetry in executing the texts and their panels as well. This inscription is a Quranic quotation ending with the foundation date and divided into three cartouches beginning with the middle which is composed of two lines; the upper is the (full) Basmala, i.e. the beginning of the text, beneath it the foundation date. Next, the Quranic verse (4:103) starts from the right cartouche and continues in the third on the left, as follows: Text

بسم اله الرحمن الرحيم / إن الصلاة كانت / على المؤمنين كتابا موقوتا / [ت]م في سنة 1300 Transliteration

bism allāh al-raḥmān al-raḥim / inna alșalata kanat / 'ala almuw'minyīn kitaba[n] mawquwta[n] / [ta]mm fi sanat 1309

Translation

In the name of God the Merciful, the Compassionate / Indeed, prayer has been/decreed upon the believers a decree of specified times / finished in the year 1309.

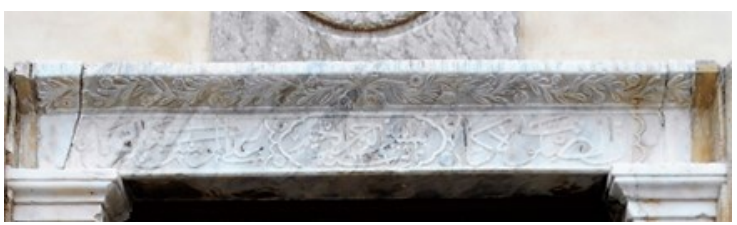

Fig. 14. Inscription no. 1

According to this inscription, the construction of the mosque finished in the year $1309 \mathrm{AH}$ (7 August 1891 -26 July 1892).

\section{Inscription Nos. 2-4 (Figs. 15-17)}

Inscriptions nos. 2-4 comprise a set of round marble panels (medallions) forming a triangle around the entrance of the mosque, pertaining the tri-unit symmetry. The higher and larger panel is the axe of symmetry.

\section{Inscription No. 2 (Fig. 15)}

Around panel with diameter 50 centimetres mortared at the height of 3.60 meters above the floor. Unfortunately, it is very poorly preserved. Its place and calligraphy style "ta?lyīq," which is used only here, refer to its specific significance. It is possible it includes the founder(s) data or relevant information. A Tughra text occupies the upper part of the panel beneath it a two-line text. Previous studies [19], [24] presumed that the Tughra text is the emblem of Sultan Abdülhamid II (1876-1909); but with the comparison of the layout, and more specifically the stand and the arms with our Tughra text here concludes that it is not the Tughra of Sultan Abdülhamid II. Presumably, the Tughra in this inscription provides a phrase of invocation for Allah or Prophet Muhammad likewise two other inscriptions in the mosque (Inscription nos. 7, 9; Figs. 21, 24). This inscription may read as follows:

Text

$$
\begin{aligned}
& \text { 1 } \\
& \text { 2. } \\
& \text { 3. 3......... [ ] }
\end{aligned}
$$

Translation

1. An invocation phrase bearing the tughra style

2. My Lord grant [?] [.........

3. In the șaray (palace) $[?][\ldots \ldots \ldots]$

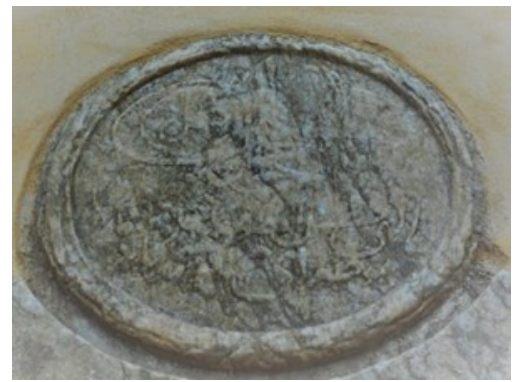

Fig. 15. Inscription no. 2

Inscriptions Nos. 3 and 4 (Figs. 16-17)

Previous studies did not account for these inscriptions [19][24]. They are similar; each one is a round panel with a diameter of 40 centimetres mortared at a height of 3.20 meters above the floor. They are very poorly preserved but fortunately better than the previous. Their texts are designed forming a decorative shape of interweaved 6-points star. However, the content of their text is different; the right panel (no. 3) reads "key of the paradise" referring to the prayer. The text of the left panel is a Quranic verse (48:1). The transliteration and translation are as follows:

Text: مفتاح الجنة

Transliteration: mftah aljanna

Translation: The key to paradise

And the left plaque composes a Quranic passage (48:1) reads as follows:

Text: إنا فتحنا لك فتحا مبينا

Transliteration: Inna fatahna laka fatha[n] mubeena[n] Translation: Indeed, We have given you, [O Muhammad], a clear conquest 


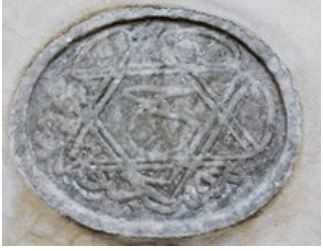

Fig. 16. Inscription no. 3

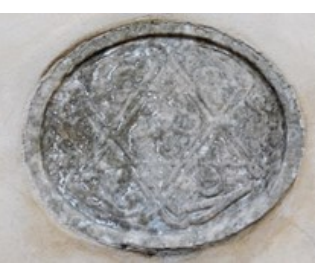

Fig. 17. Inscription no. 4
Inscriptions Nos. 5 and 6 (Figs. 18-19)

These two inscriptions of the minaret are in Ottoman script. Greek and English translations of both are published [19], [24]; without publishing the Ottoman text or any commentaries. The first is a rectangular stone $60 \times 70$ centimetres in the center of the southern wall of the minaret at the height of 4.70 meters above the floor. It is composed of a four-line text, which reads:

Text

$$
\begin{aligned}
& \text { 1. } \\
& \text { 2. } \\
& \text { 3. }
\end{aligned}
$$

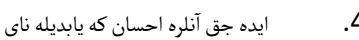

Translation

1. Let all those who like doing charities to erect this building.

2. Specifically, the family of Pabougigy zade[?] to accomplish this building.

3. This building, collaborative construction of righteous people, to be benevolent for all poor of Crete.

4. May this charitable which erected to them (people of Crete) to be memorized eternally.

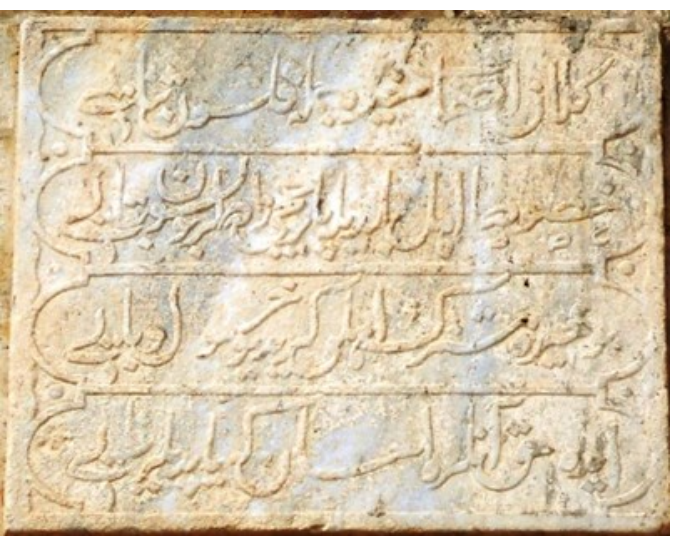

Fig. 18. Inscription no. 5

The importance of this inscription exceeds all expectations; it cites that the mosque is a collaboration of Crete's People and specifically the family of Pabougigy zade, one of the Turkish families of the lerapetra city. This reference characterizes this mosque as being particularly rare, uniquely preserved and built by civil society with unique construction in contrast to that of those constructed by members of the ruling class or the grand commanders.

The second inscription here (no. 6) is a rectangular stone plaque 30 by 70 centimeters, centered in the western wall of the minaret at a height of 5 meters above the floor. It is composed of two-line text, which reads:

Translation:

$$
\text { 2. }
$$

1. Selim Bahjila Vsjaki[s] who is fond of doing charitable works.

2. the greedy to enter paradise by constructing this beautiful building.

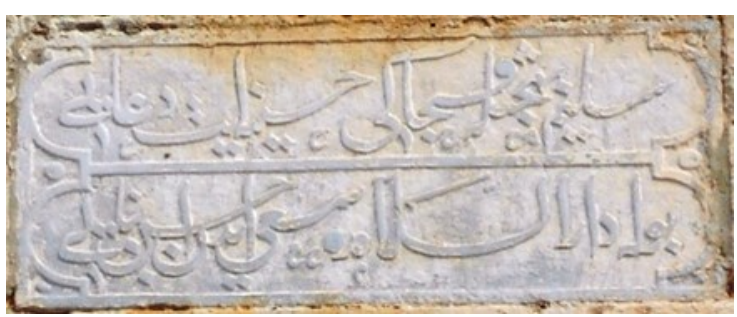

Fig. 19. Inscription no. 6

This inscription provides the name of one of the people who participated in constructing the mosque. He is Selim Bahjila Vsjaki[s], according to his name he was a Greek Muslim, perhaps the second generation. He kept his Greek family name and cited it here proudly. He could also alternatively be the sponsor for building the minaret specifically.

\section{Inscription No. 7 (Figs. 20-21)}

There is a round panel with a 50-centimeter diameter mortared at the center of the qibla wall on the exterior, at height 4.35 meters above the floor, corresponding with a similar one above the mihrab (No. 9). Previous studies [19], [24] referred to this inscription as "a medallion with the signature of the Sultan Abdülhamid II and the Hijra year 1309 [A.D.1891/1892]". This attribution to the Sultan Abdülhamid II is completely wrong; the text starts from the upper right part and continues as follows:

Text:

$$
\begin{aligned}
& \text { 1. } \\
& \text { 2. } \\
& \text { 3. } \\
& \text { 4. } \\
& \text { 5. }
\end{aligned}
$$

Translation:

1. The Prophet peace be upon him said.

2. In the name of God the Merciful, the Compassionate.

3. is the key to each door.

4. [fini]shed in the year 1309 [1891/1892].

5. Who hopes to stay in Mecca [?].

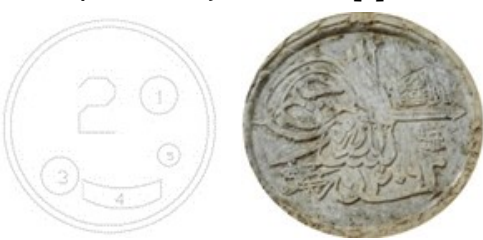

Fig. 20. The layout of the content of the inscription no. 7 Fig. 21. Inscription no. 7 
It indicates that it is a hadith or saying of the Prophet Muhammad. The full Basmala here forms part of the hadith scribed in Tughra, and the last phrase refers to the pseudonym of the scriber.

\section{Inscription No. 8 (Fig. 22)}

It is also placed on the qibla wall about 2.5 meters above the former inscription. It is a rectangular marble plaque 33 by 90 centimetres, composed of one-line of an intertwined Quranic quotation (24:36), which reads: Text:

$$
\text { قال الله عز وجل [:] في بيوت أذن الله أن ترفع ويذكر فيها اسمه [.] صدق الله }
$$

Transliteration: qala Allahu 'azza wa djall [:] Fee buyout [in] adina Allahu an turfa'a wayudkaro feeha ismuhu [.] sadaqa Allahu

Translation: Allah, the Exalted, the Majestic said [:] in houses (mosques) which Allah has ordered to be raised and that His Name be mentioned there in [.] Allah has spoken the truth.

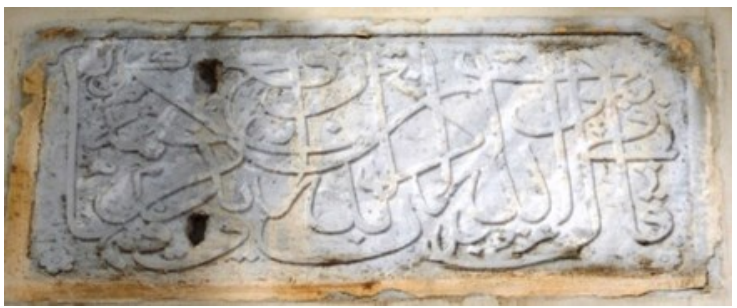

Fig. 22. Inscription no. 8

Previous studies [19] [24] referred to this inscription as "a virtually illegible Arabic inscription". In addition, it has two small openings suggesting the reuse of this marble plaque.

Inscription No. 9 (Figs. 23-25)

There is a round panel with a 50-centimeter diameter placed above the mihrab of the mosque, at height 4.35 meters above the floor. Previous studies [19], [24] referred to this inscription as "an inverted medallion with an illegible Arabic inscription". Its text starts from the upper right part and continues as follows:

$$
\begin{aligned}
& \text { 1. } \\
& \text { 2. }
\end{aligned}
$$

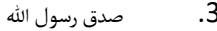

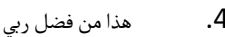

Translation:

1. Peace be upon him said.

2. My intercession (shafa'a) is for the people who commit majors sins amongst my nation (Umma).

3. The Messenger of Allah has spoken the truth.

4. It is by the grace of my Lord.

It signifies a hadith or saying of the Prophet Muhammad, the core hadith (nu.2) scribed in Tughra, and the last phrase is a Quranic quotation (27: 40).

The inverted round plaque mentioned above (Fig. 25) (the correct placement as shown in Figure 24) is broken into two halves; this incorrect viewpoint was probably a result of repositioning the plaque after being broken.

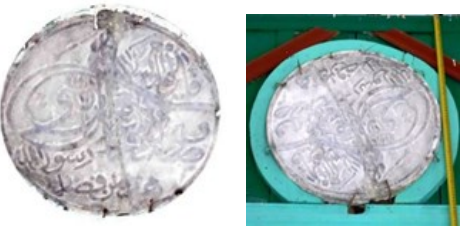

Fig. 23. The layout of the content of the inscription no. 9

Fig. 24. The correct, legible position of the inscription no. 9

Fig. 25. The current illegible location of the inscription no. 9

\section{Inscription No. 10 (Fig. 26)}

It is mortared on the most eastern part of the qibla wall at a height of 3.25 meters above the floor. It is a $24 \times 95$ centimeter rectangular marble plaque, composed of one-line text, the shahada or the profession of faith (لا إله إلا الله محمد رسول الله).

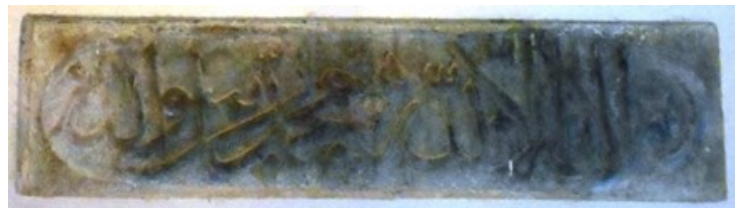

Fig. 26. Inscription no. 10

The rectangular shape of this inscriptive plaque and its calligraphy style and size suggest it dates to an earlier period than the other 19th century inscriptions of the Mosque suggesting it belongs to the older mosque thought to in the place of this current mosque.

\section{Inscription No. 11 (Fig. 27)}

The most beautiful inscription, in both design and calligraphy style, is one of the ablution fountains to the west of the mosque. Its southern side ends with two fronted fine-carved snakeheads opening their jaws holding the inscription. It is a circular plaque, surrounded by a carved wreath. It is written in Ottoman script, characterized with the returning tail of the final letter ya', which used twice to divide the text into three tiers, on the commemoration of Mamluk Sultan. It reads as follows:

$$
\begin{aligned}
& \text { 1. } \\
& \text { 2. } \\
& \text { 3. }
\end{aligned}
$$

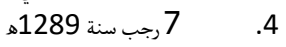

Translation:

1. Founder of the charities and seeker

2. of the awards Maqaronaki[s] 'Ali

3. God granted him with his great grace

4. 7 Rajab in the Hija year 1289

The separated ablution fountain is connected with the proper mosque complex. In this context, this is the oldest dating inscription. It dates precisely to 7 Rajab $1289 \mathrm{AH}$ (10 Sep. 1872). It is a good example of this system of dating with the day/month/year and the day according to the Indian numerical system. Thus, this ablution fountain dates back two decades earlier than the mosque. It provides us with the name of its founder Maqaronaki[s] 'Ali. According to his name, he 
was a Greek Muslim, perhaps a second generation. He kept his Greek family name and cited it here proudly.

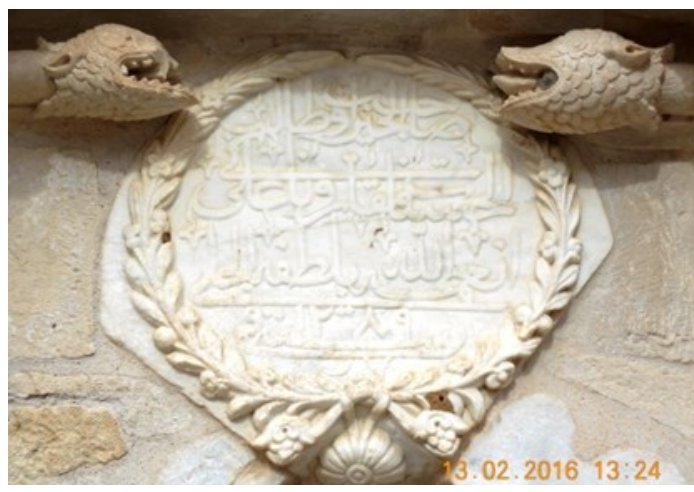

Fig. 27. Inscription no. 11

\section{RESULT AND DISCUSSION}

The architecture of the lerapetra Mosque and its inscriptive program, as discussed above, in addition to its strategic site, strongly suggest that the current mosque is a reconstruction of an older mosque which may have been destroyed in the earthquake of 1870 . This earthquake was so powerful that the fort was destroyed and the 300 soldiers Turkish garrison was killed. In light of this theory, we can say the date the ablution fountain was built two years later in 1872 . The construction date of the ablution fountain, 1872, matches with the above theory.

The discrepancy between the two dates 1872 and $1891 / 1892$ of the ablution fountain, and the proper mosque respectively, in addition to the inscriptions, highlight how the stages of the building were executed in light of the function and the relevant context.

Circumstances in lerapetra, like all regions in Crete, were difficult during the last decades of the 19th century because of the conflict between the Ottoman Empire, the western powers and the Greek revolution. The Ottomans lost their power and their pre-eminence gradually till their complete withdrawal in 1905. Moreover, if we take into consideration the results of the devastating earthquake of 1970 , the absence of the state's role or its representatives of commanders as patrons of constructing mosques, as usual, is understandable. Incidentally, Muslims were the majority of the inhabitants of the city according to the census completed in 1881 in which lerapetra was shown as the seat of a municipality of 1070 Christian and 1430 Muslim inhabitants. Thus, we can conclude, the lerapetra mosque is a work of contributions of the city's Muslim community, as declared the inscription on the minaret's base (Inscription no. 5, Fig. 18).

In the context above, the ablution fountain was built first, or reconstructed, based on reasons, first, the function - ablution is compulsory for prayer, and secondly, its structure - comparatively low cost in comparison with the proper mosque. Since the contributing process was mandatory and selective; Al Maqaronaki[s], a Greek Muslim, as mentioned above, sponsored the construction of the ablution fountain.

Regarding the proper mosque, it is important to note that the congregational prayer did not stop during the reconstructing. It continues simultaneously. There are no architectural requirements for worship. In terms of the priority, the architectural details and the cost the prayer hall should have been finished first, then the minaret, and finally the portico.

The second inscription of the minaret provides us with another name of the patrons of the mosque, Selim Bahjila Vsjaki[s], also a Greek Muslim, as mentioned above, and who likely paid a major contribution in the mosque (re)construction or the sponsor of building the minaret.

Names of the two Greek Muslims recorded in the inscriptions are named without any titles or positions with no indications of the contribution of any commanders or high ranking officials. Thus, the nature of the patronage here stands in contrast to those of the grand commanders of the Early Ottoman State such as Gedik Ahmad Pasha (d. 1482), and his family; however both of Christian origin [25].

Based on the information that lyverdi provided on the ottoman mosques in Greece, there were 966 mosques had been built in the villages [26]. Of which most supposed to be founded by the villagers themselves or by the village people.

Unfortunately, these village-mosques, except Thrace-which continued till now; restored or reconstructed by the villages' people in most cases- and rare examples in Greek islands, do not exist. Today, there are 235 mosques (camii and mescid) in Greek "or Western" Thrace (Xanthi, Rhodope, and Evros), where still live a minority Muslim. The greatest number of these mosques is in the villages [27]

Above clues refer to a change like the Ottoman state rule, reflecting the difficulties they have faced at that particular time in almost all Greek regions. An echo of that change was the shifting in the patronage of the construction of mosques replacing grand commanders or officials with the Muslim community as patrons of mosque construction.

In summary, the lerapetra Mosque is a unique preserved example of the Ottoman mosques in Greece; it is not built with typical patronage. Instead, it was constructed by the contribution of the Muslim community of lerapetra city. Among which were two Greek Muslims; their legacy is inscribed therein as the main patrons of the Mosque.

\section{ACKNOWLEDGEMENTS}

The research in the libraries and in the field which forms the base of this article was done thanks to the short term postdoctoral mission ( 3 months) funded by the Onassis Foundation (Greece). This Article is accomplished thanks to the license of studying, photographing and publishing from the Ephorate of Antiquities of Lasithi, General Directorate of Antiquities and Cultural Heritage (Hellenic Ministry of Culture and

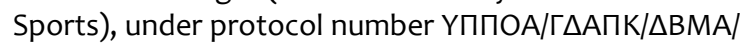
TEEAEI/98341/60064/2144/208 (10.7.2017).

We thank colleagues and friends Marina Demetriadou, Dafni Chronaki, Mariana Katifori, Chryssoula Kritsotala- 
ki for their great help that facilitated my visit to lerapetra. We would also like to show our gratitude to the authors of previous related contributions that greatly improved the manuscript, with particular thanks to Professor Elias Kolovos and Archaeologist Maria Mari. We are also immensely grateful to Professor Machiel Kiel and Professor Mohamed Uthman for their comments on an earlier version of the manuscript, although any errors are only our own.

\section{REFERENCES}

[1] N. Steinhardt, "China's Earliest Mosques," Journal of the Society of Architectural Historians, Vol. 67, pp. 330-361, Sep. 2008.

[2] E. Baldissera, al-Kitābāt fi l-masāğid alumāniyya al-qadima [=Inscriptions of the Old Mosques in Oman], Ministry of National Heritage and Culture, Muscat, 1994.

[3] A. Ameen, Islamic Architecture in Greece: Mosques. Foreword: Dr. Mostafa El Feki, Center for Islamic Civilization studies, Bibliotheca Alexandrina, Alexandria, 2017.

[4] H. W. Lowry, The Evrenos Family \& the City of Selânik (Thessaloniki): Who Built the Hamza Bey Câmi'i \& Why? , Istanbul: Bahçe?]ehir University Press, 2010.

[5] Evliyâ Çelebi, Evliyâ Çelebi Seyahatnâmesi. Seyit Ali Kahraman, Yücel Dağlı and Robert Dankoff. (Eds.), vol. 8. İstanbul: Yapı Kredi Yayınları, 2003.

[6] M. Kiel, "Observations on the History of Northern Greece during the Turkish Rule: Historical and Architectural Description of the Turkish Monuments of Komotini and Serres, their Place in the Development of Ottoman Turkish Architecture and their Present Condition", BSt 12 (1971), 426-456.

[7] H. W. Lowry, The Shaping of the Ottoman Balkans 1350-1550: The Conquest, Settlement and Infrastructural Development of Northern Greece. Istanbul: Bahçeşehir University Publications, 2008.

[8] M. Hartmuth, "The Princess and the Mosque: Ottoman Royal Women's Architectural Patronage in the Province and the Case of the socalled Zincirli Câmi' at Serres". In Juliette Dumas and Sabine Frommel (Eds.), Bâtir au féminin? Traditions et stratégies en Europe et dans l'Empire ottoman. Paris: Picard, 2013, 79-88.

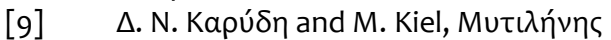

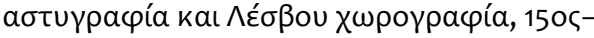

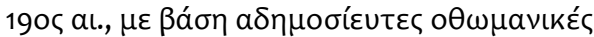

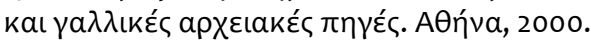

[10] H. W. Lowry, Ottoman Architecture in Greece: A Review Article with Addendum and Corrigendum. Istanbul: Bahçeflehir University Press, 2009.

[11] M. Baer, "Globalization, Cosmopolitanism, and the Dönme in Ottoman Salonica and Turkish Istanbul." Journal of World History 18/2 (June 2007), $141-170$.

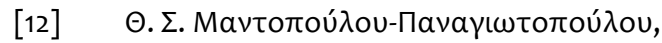

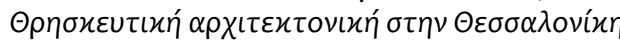

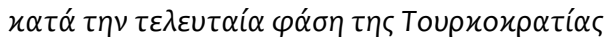

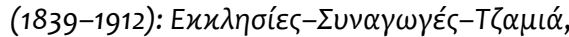

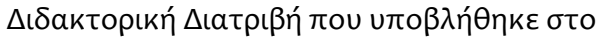

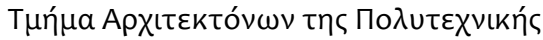

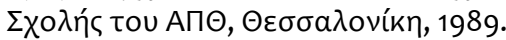

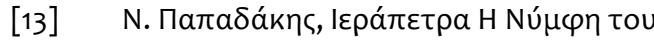

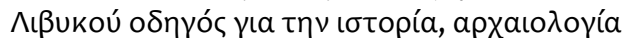

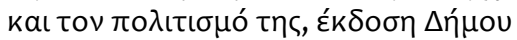

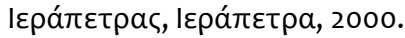

[14] Salnâme-i Vilayet-i Girid 1310 (26-7-1892/14-71893)

[15] Salnâme-i Vilayet-i Girid 1292 (7-2-1875/27-11876)

[16] Salnâme-i Vilayet-i Girid 1309 (7-8-1891/25-71892)

[17] L. S. Stavrianos, The Balkans since 1453, New York: Rinehart, 1958.

[18] "Mosque of Ankebut Ahmet Paşa (?) in lerapetra." Retrieved from: http:// digitalcrete.ims.forth.gr/ tourkology_monuments_display.php? $\mathrm{I}=1 \& \mathrm{id}=280$ [Access date 6 Feb. 2016]

[19] M. Mari, “Mosque of lerapetra", In Ottoman Architecture in Greece. In Brouskari, E. (Ed.) Athens, 2008.

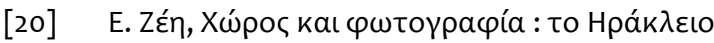

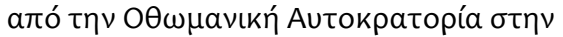

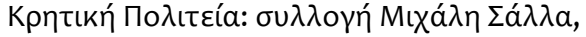

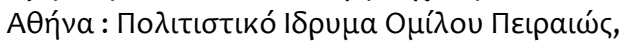
2005.

[21] Ch. D. Bardes, “Caduceus", Agni, No. 63 (2006), 235-238.

[22] S. Şahin and Ş. Sönmezer, "Osmanli Mimarisinde Figürlü Tasvir Sanati Hakkinda Daha Önce Bilinmeyen Bir Örnek: I. Mahmut Su Kemeri”, Sanat Tarihi Yıllığı Sayı 26, 2014, İstanbul Üniversitesi Edebiyat, İstanbul, 2017, 105-140.

[23] M. A. Othman and A. M. Al-Emam, "Mosque Architecture in Response to Sharia Rules: An Applied Study of Historic Mosques", Symposium on Mosque Architecture, Vol. 8: Mosque architecture according to the Sharia rules, College of architecture and planning, King Saud University, Riyadh 1999, 133-160.

[24] Mosque of lerapetra. Retrieved from: http:// digitalcrete.ims.forth.gr/ tourkology monuments display.php?id=172\&l=1 [Access date 6 Feb. 2016]

[25] H. W. Lowry, The Nature of the Early Ottoman State, Albany: State University of New York Press, 2003.

[26] E.H. Ayverdi, Avrupa'da Osmanli Mimari Eserleri IV: Bulgaristan, Yunanistan, Arnavutluk. Istanbul: Istanbul Fetih Cemiyeti, 1982.

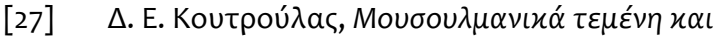

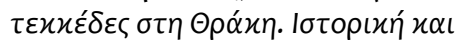

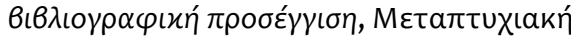

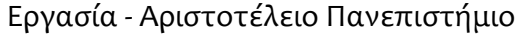

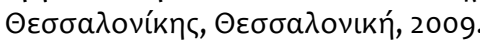

